\title{
Chemically-resolved aerosol eddy covariance flux measurements in urban Mexico City during MILAGRO 2006
}

\author{
R. Zalakeviciute ${ }^{1,{ }^{*}}$, M. L. Alexander ${ }^{2}$, E. Allwine ${ }^{3}$, J. L.Jimenez ${ }^{4}$, B. T. Jobson ${ }^{3}$, L. T. Molina ${ }^{5}$, E. Nemitz ${ }^{6}$, \\ S.N. Pressley ${ }^{3}$, T. M. VanReken ${ }^{3}$, I. M. Ulbrich ${ }^{4}$, E. Velasco ${ }^{7}$, and B. K. Lamb ${ }^{3}$ \\ ${ }^{1}$ Department of Ecology and Evolutionary Biology, Cornell University, Ithaca, NY, USA \\ ${ }^{2}$ Pacific Northwest National Laboratory, Richland, WA, USA \\ ${ }^{3}$ Laboratory for Atmospheric Research, Washington State University, Pullman, WA, USA \\ ${ }^{4}$ Department of Chemistry \& Biochemistry, University of Colorado, Boulder, CO, USA \\ ${ }^{5}$ Molina Center for Energy and the Environment (MCE2), USA \\ ${ }^{6}$ Centre for Ecology and Hydrology, Edinburgh, UK \\ ${ }^{7}$ Center for Environmental Sensing and Modeling, Singapore \\ * formerly at: Laboratory for Atmospheric Research, Washington State University, Pullman, WA, USA
}

Correspondence to: B. K. Lamb (blamb@wsu.edu)

Received: 29 February 2012 - Published in Atmos. Chem. Phys. Discuss.: 9 May 2012

Revised: 2 August 2012 - Accepted: 11 August 2012 - Published: 31 August 2012

\begin{abstract}
As part of the MILAGRO 2006 field campaign, the exchange of atmospheric aerosols with the urban landscape was measured from a tall tower erected in a heavily populated neighborhood of Mexico City. Urban submicron aerosol fluxes were measured using an eddy covariance method with a quadrupole aerosol mass spectrometer during a two week period in March, 2006. Nitrate and ammonium aerosol concentrations were elevated at this location near the city center compared to measurements at other urban sites. Significant downward fluxes of nitrate aerosol, averaging $-0.2 \mu \mathrm{g} \mathrm{m}^{-2} \mathrm{~s}^{-1}$, were measured during daytime. The urban surface was not a significant source of sulfate aerosols. The measurements also showed that primary organic aerosol fluxes, approximated by hydrocarbon-like organic aerosols (HOA), displayed diurnal patterns similar to $\mathrm{CO}_{2}$ fluxes and anthropogenic urban activities. Overall, $47 \%$ of submicron organic aerosol emissions were HOA, $35 \%$ were oxygenated (OOA) and $18 \%$ were associated with biomass burning (BBOA). Organic aerosol fluxes were bidirectional, but on average HOA fluxes were $0.1 \mu \mathrm{g} \mathrm{m}^{-2} \mathrm{~s}^{-1}$, OOA fluxes were $-0.03 \mu \mathrm{g} \mathrm{m}^{-2} \mathrm{~s}^{-1}$, and BBOA fluxes were $-0.03 \mu \mathrm{g} \mathrm{m}^{-2} \mathrm{~s}^{-1}$. After accounting for size differences $\left(\mathrm{PM}_{1}\right.$ vs $\left.\mathrm{PM}_{2.5}\right)$ and using an estimate of the black carbon component, comparison of the flux measurements with the 2006 gridded emissions inventory of Mexico City, showed
\end{abstract}

that the daily-averaged total PM emission rates were essentially identical for the emission inventory and the flux measurements. However, the emission inventory included dust and metal particulate contributions, which were not included in the flux measurements. As a result, it appears that the inventory underestimates overall PM emissions for this location.

\section{Introduction}

Atmospheric aerosols are complex pollutants having considerable direct and indirect effects on environmental quality and climate change (Forster et al., 2007). Studies over the last decade also consistently show statistically significant correlations between cardiopulmonary mortality and daily concentrations of particulate matter (PM), $\mathrm{PM}_{10}$ and in particular of $\mathrm{PM}_{2.5}$ (PM with aerodynamic diameter less than 10 and $2.5 \mu \mathrm{m}$, respectively) and the length of exposure (Pope and Dockery, 2006). Aerosol chemical components are classified as primary when they are directly emitted in the particle phase and secondary when they are formed in the atmosphere from gaseous precursors. In typical urban environments, about $25-75 \%$ of the $\mathrm{PM}_{2.5}$ mass is inorganic, mainly composed of the secondary species ammonium 
$\left(\mathrm{NH}_{4}^{+}\right)$, sulfate $\left(\mathrm{SO}_{4}^{2-}\right)$, and nitrate $\left(\mathrm{NO}_{3}^{-}\right)$, but it can also include primary sodium $\left(\mathrm{Na}^{+}\right)$and chloride $\left(\mathrm{Cl}^{-}\right)$and crustal elements (Heintzenberg, 1989). Unlike the inorganic aerosol component, the organic aerosol (OA) is composed of thousands of individual compounds. While a small fraction of inorganic aerosol components may be associated with organonitrates and organosulfates, in this paper we still use inorganic component nomenclature with the charges (e.g. $\mathrm{SO}_{4}^{2-}$ ) (for more information see Farmer et al. 2010). The Aerodyne Aerosol Mass Spectrometer (AMS) (Canagaratna et al., 2007) has emerged as a valuable tool to provide an indication of the make-up of the organic aerosol (OA) mass. The application of statistical techniques such as Positive Matrix Factorization (PMF, see Sect. 2.4 below) to the AMS mass spectra often identifies individual OA components that are consistent between studies (Ng et al., 2010, 2011). Primary organic aerosols (POA) are directly emitted from natural or anthropogenic sources, such as fossil fuel combustion, cooking, and other urban sources. These are usually identified by an AMS factor referred to as hydrocarbon-like OA (HOA), but cooking aerosols are increasingly identified separately (Allan et al., 2010) or as part of the aerosols associated with biomass burning (BBOA). Secondary organic aerosols (SOA) are formed by atmospheric oxidation of gasphase species (Jimenez et al., 2009) and are identified as oxygenated organic aerosols (OOA) due to their characteristic mass spectrum with high oxygen content. The OOA sometimes can be divided into sub-classes. Low-volatility OOA (LV-OOA), characterized by a high O:C ratio, is associated with regional and aged SOA (Jimenez et al., 2009; Cappa and Jimenez, 2010). Semi-volatile OOA (SV-OOA) has a lower $\mathrm{O}: \mathrm{C}$ ratio, and is associated with less photochemically aged SOA (Jimenez et al., 2009).

A substantial fraction of particulate pollution is produced by industry and transportation in urban areas and is recognized to influence regional and global atmospheric chemistry (Lawrence et al., 2007). Anthropogenic pollution problems have been intensified by the rapid urbanization and the growing number of megacities (population exceeding 10 million inhabitants). Currently, about $58 \%$ of the global population lives in urban areas, which have a population growth rate 18 times higher than in the rural areas (UN, 2010). Thus, in order to reliably predict future impacts on environment and human health, it is essential to understand the sources, chemical nature, evolution, and fate of urban pollution. The Megacity Initiative: Local and Global Research Observations (MILAGRO) 2006 field campaign, conducted in Mexico City during March 2006, was an international initiative designed to study these topics (Molina et al., 2010). One research focus during MILAGRO was the exchange of mass and energy between the urban surface and the atmosphere. Using fast response sensors coupled with eddy covariance (EC) methods, fluxes of chemically-resolved submicron aerosols, selected volatile organic compounds (VOCs), $\mathrm{CO}_{2}$, and components of the energy balance were measured in a typical residen- tial and commercial neighborhood of Mexico City. Ambient $\mathrm{NO}_{\mathrm{x}}, \mathrm{CO}$, and $\mathrm{O}_{3}$ concentrations were also measured. Analyses of fluxes of VOCs and $\mathrm{CO}_{2}$ and the local energy balance have been reported by Velasco et al. $(2009 ; 2011)$. In this work, we present results from the aerosol flux measurements.

Integral aerosol mass and number fluxes have been reported for a few urban sites (Dorsey et al., 2002; Vogt et al., 2011), This work extends this approach to measure urban EC fluxes of individual aerosol chemical components using an Aerodyne Quadrupole Aerosol Mass Spectrometer (Q-AMS). We follow the approach described by Nemitz et al. (2008) for Boulder, CO (USA), which has since been applied to measure chemically resolved fluxes above Gothenburg (Sweden), and in London, Manchester, and Edinburgh (all in the UK) (Thomas, 2007; Nemitz et al., 2008). Here, we present the first chemically resolved urban aerosol EC fluxes for an arid, subtropical megacity. The objectives of this study were to investigate daily patterns of aerosol concentrations and fluxes over a megacity landscape, identify the sources and sinks for organic, nitrate and sulfate aerosols, and, to the extent possible, compare the measurements with the existing gridded emissions inventory of Mexico City.

\section{Methods}

\subsection{Experimental setup and study period}

The flux measurements were conducted in a populated neighborhood (Escandon district: $19^{\circ} 24^{\prime} 12.63^{\prime \prime} \mathrm{N}$, $99^{\circ} 10^{\prime} 34.18^{\prime \prime} \mathrm{W}, 2240 \mathrm{~m}$ above sea level) near the center of Mexico City and surrounded by a dense road network including several major avenues (Fig. 1). Following the local climate zone classification proposed by Stewart and Oke (2010), the monitored urban surface corresponds to "compact housing". The predominant land use is residential and commercial with $57 \%$ of the surface covered by buildings of three and four stories high; roadways and other impervious surfaces accounted for $37 \%$, and vegetation covered the remaining $6 \%$. The site is completely flat with a relatively homogeneous distribution of roughness elements (i.e., buildings and trees) and emission sources (i.e., vehicular traffic).

A $25 \mathrm{~m}$ scaffold tower was erected on the roof of a $17 \mathrm{~m}$ tall building housing the headquarters of the local air quality management agency, SIMAT (see Fig. S1). The aerosol sample inlet and a 3-D sonic anemometer (Applied Technologies, Inc., Longmont, $\mathrm{CO}$ ) were positioned on the end of a $3 \mathrm{~m}$ boom at $42 \mathrm{~m}$ above the ground. This height is more than 3 times the average height of the surrounding buildings $\left(z_{\mathrm{h}}=12 \mathrm{~m}\right)$ and sufficient to be in the constant flux layer. As indicated previously, fluxes of selected VOCs, $\mathrm{CO}_{2}$, and sensible and latent heat were measured at this site using EC methods. Ambient $\mathrm{NO}_{\mathrm{x}}, \mathrm{CO}$, and $\mathrm{O}_{3}$ concentrations were 


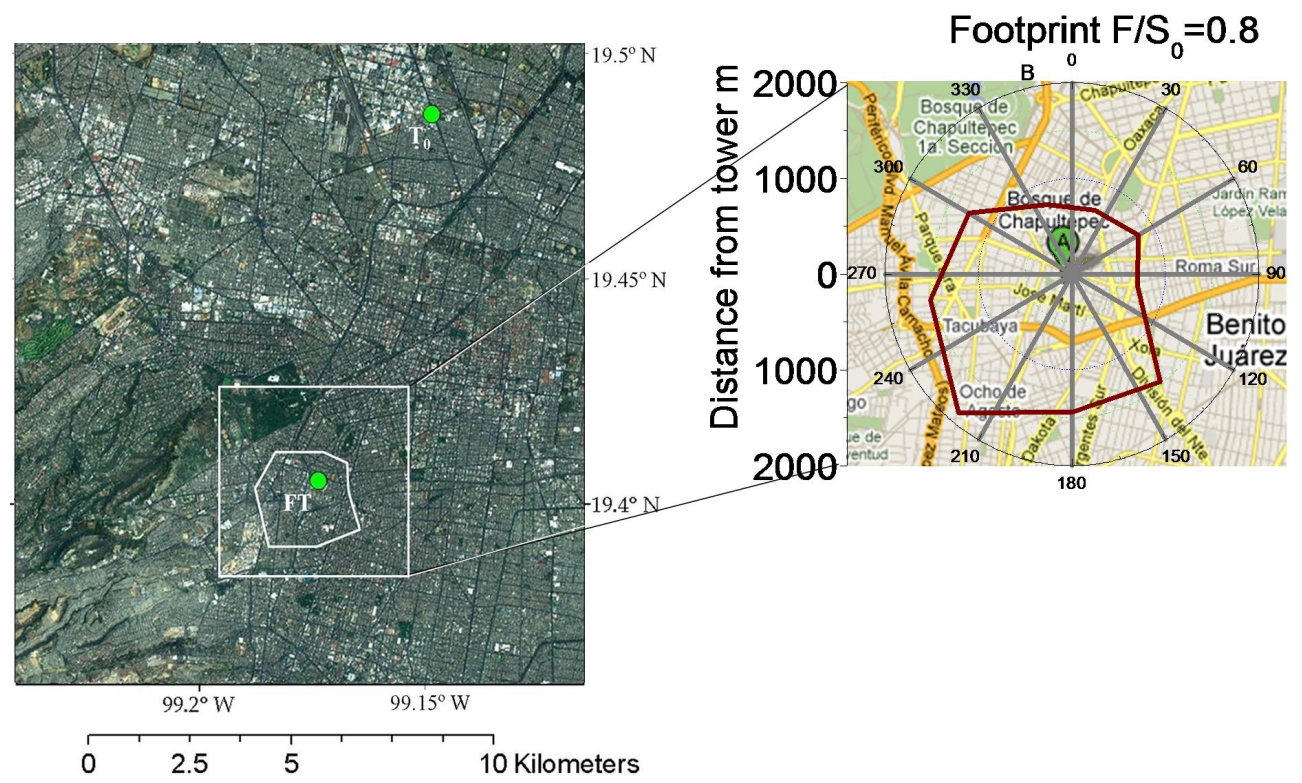

Fig. 1. Aerial photograph of Mexico City showing the MILAGRO $T_{0}$ and SIMAT flux tower (FT) sites with green dots. The white contour indicates the footprint that accounted for $80 \%\left(\mathrm{~F} / \mathrm{S}_{0}=0.8\right)$ of the measured aerosol fluxes during the entire study as a function of the wind direction. The aerial photograph was taken from ArcMap. The insert to the right shows the flux footprint plotted over the area map (Google Maps) immediately around the tower.

also measured at the roof level. Additional details are given by Velasco et al. $(2009,2011)$

For the aerosol flux measurements, air was drawn at a high rate $(\sim 60 \mathrm{slpm})$ through a $1.6 \mathrm{~cm}(5 / 8 ”)$ outer diameter (OD) $27 \mathrm{~m}$ long copper sampling line down to a pump located on the roof of the building. A second smaller pump was used to draw sample air from the copper line upstream of the large pump through a $0.6 \mathrm{~cm}\left(1 / 4^{\prime \prime}\right)$ OD $1 \mathrm{~m}$ long stainless steel tubing into the Q-AMS (Aerodyne Research, Inc, Billerica, MA) located in a small penthouse room on the roof. Data were recorded at $10 \mathrm{~Hz}$ for both the Q-AMS and sonic anemometer using custom Q-AMS flux data acquisition software (Nemitz et al., 2008) and LabView (National Instruments) software, respectively.

Aerosol fluxes were measured during the period 12-30 March 2006. However, the week of 18-24 March was excluded from the data analysis due to unstable instrument operations caused by frequent power outages in the residential area. The remaining two sampling periods were characterized by different meteorological conditions. In the first period, conditions were warm and mostly sunny with frequent wildfires in the surrounding mountains (see Fig. S2), while in the second period, conditions were more humid with frequent afternoon precipitation and wildfires were strongly suppressed (Fast et al., 2007; Aiken et al., 2010) (Fig. 2).

The data are presented in local time and ambient conditions. Aerosol concentrations are shown in $\mu \mathrm{g} \mathrm{m}^{-3}$ and fluxes in $\mu \mathrm{g} \mathrm{m}^{-2} \mathrm{~s}^{-1}$. In this article we refer to positive (upward) fluxes as emissions and negative (downward) fluxes as deposition although these can include formation or loss of aerosols within the urban canopy below the measurement height.

\subsection{The Aerodyne Quadrupole Aerosol Mass Spectrometer (Q-AMS)}

The aerosol mass composition was measured using a QAMS. The design and operation of the standard Q-AMS were introduced by Jayne et al. (2000) and Jimenez et al. (2003) and are only briefly described here. In this instrument, a sample stream of ambient air (approximately $1.5 \mathrm{~cm}^{3} \mathrm{~s}^{-1}$ during this study) passes through an aerodynamic lens (of transmission approximating $\mathrm{PM}_{1}$ ) that focuses particles into a narrow beam. As the beam of particles enters a differentially pumped vacuum chamber, a spinning chopper wheel (2\% opening) modulates the beam to allow all, a few, or no particles into the chamber. Particles drift through the vacuum chamber (particle time-of-flight region) and impact onto a heated surface $\left(\sim 600^{\circ} \mathrm{C}\right)$ where non-refractory components are flashvaporized into gases. The gaseous species are then ionized by $70 \mathrm{eV}$ electron impact, and the ions are mass analyzed with a quadrupole mass spectrometer (QMS). The concentration and sizing of the Q-AMS were calibrated with standard procedures (Canagaratna et al., 2007) and the data were analyzed by the standard Igor-Pro (Wavemetrics, Lake Oswego, OR) data analysis software (version Deluxe1.37.ipf) following Allan et al. (2004). 


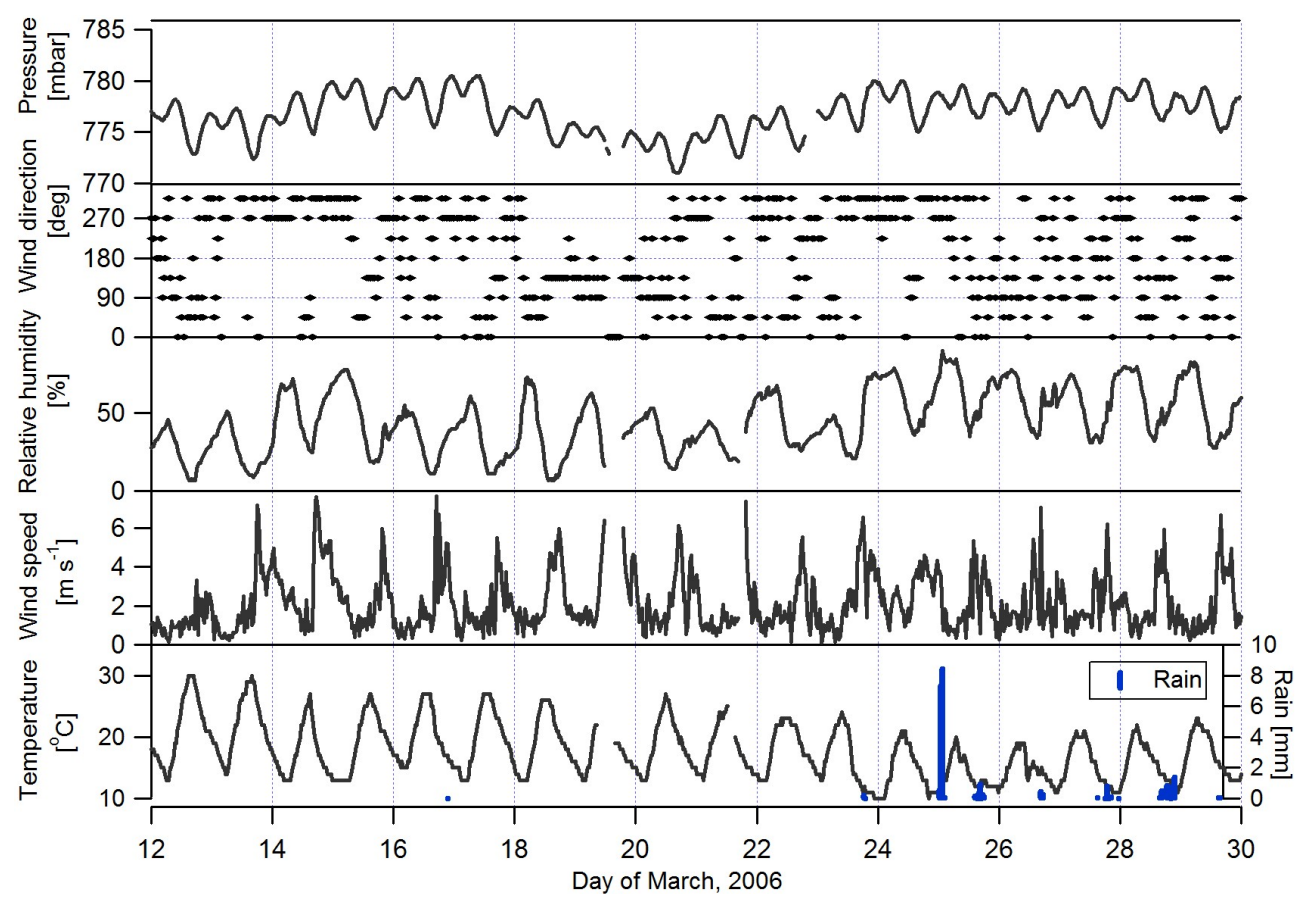

Fig. 2. Pressure, wind direction, relative humidity, wind speed, ambient temperature, and precipitation (right axis) data at 30 min time step measured at the SIMAT site during the observation period.

\subsection{Operation modes}

During the field campaign, the Q-AMS was operated in alternating modes for 30-min periods to measure either concentrations or fluxes, respectively. These modes of operation have been described in detail by Jimenez et al. (2003) and Nemitz et al. (2008), and they are only briefly reviewed here. In the concentration mode ("general alternation" or GenAlt mode), the instrument alternated among three submodes ( $20 \mathrm{~s}$ in each submode cycled during a $2.5 \mathrm{~min}$ averaging period) in order to measure: (i) particle size-resolved composition (particle time of flight (PToF) submode), (ii) ensemble composition for $\mathrm{m} / \mathrm{z}, 12-300$ without size resolution (mass spectrum (MS) submode), and (iii) ensemble composition at selected $\mathrm{m} / \mathrm{z}$ only (jump mass spectrum (JMS) submode (Crosier et al., 2007). Each submode is described in more detail below. In the second 30-min mode (Flux mode), the instrument was used only in the JMS mode to measure selected $\mathrm{m} / \mathrm{z}$ at a rate fast enough for EC flux calculations. In Flux mode there was a 1-min background measurement followed by $29 \mathrm{~min}$ of ambient measurement. This approach to splitting each hour yields particle size data and ensemble mass spectra of aerosol composition during one 30-min period, and fast measurements at selected $\mathrm{m} / \mathrm{z}$ suitable for flux calculations in the second 30-min period. During MILAGRO, the ions selected for the PToF and JMS mode analyses were: $\mathrm{m} / \mathrm{z} 9$ (for quantification of drifts on DC level of the signal); $m / z 28$ for the airbeam $\left(\mathrm{N}_{2}^{+}\right.$, used to track instrument sensitivity variations); $m / z, 30$ and 46 for nitrate (representing mostly $\mathrm{NO}^{+}$and $\mathrm{NO}_{2}^{+}$); $\mathrm{m} / z 48$ and 64 for sulfate (mostly $\mathrm{SO}^{+}$and $\mathrm{SO}_{2}^{+}$); and $m / z 31,43,55$ and 57 for organic species (Jayne et al., 2000). The dominance of the inorganic ions at the nitrate and sulfate masses during MILAGRO was verified by Aiken et al. (2009) (see Fig. S18 in that paper).

\subsection{Estimation of organic components using Positive Matrix Factorization (PMF)}

To divide the organic aerosol mass into individual components, a PMF analysis was performed on the organic mass spectrum, which was determined from the total Q-AMS spectrum using the fragmentation table approach (Allan et al., 2004). PMF solves the bilinear unmixing model in which, for each sample, the measured data can be reconstructed as the sum of the products of the representative chemical profiles for each component (here, aerosol mass spectrum) and the mass concentrations of those components (Paatero and Tapper, 1994; Paatero, 1997). PMF was applied to the organic portion of the aerosol obtained in the MS submode, which contain the full structure of the mass spectra and thus the most chemical information (Ulbrich et al., 2009). The PMF2 (Paatero, 2007) algorithm (version 4.2) was used in the robust mode and analysis was performed with the PMF Evaluation Tool (PET) (Ulbrich et al., 2009). VOC and CO measurements at the SIMAT site were used to help interpret and evaluate the PMF results. The PMF analysis of the organic aerosol identified three components (HOA, OOA, and BBOA) which are consistent with those identified in previous 
studies in Mexico City (Aiken et al., 2009; Dzepina et al., 2009; DeCarlo et al., 2010; Ulbrich et al., 2012).

\subsection{Eddy covariance flux calculations and system validation}

The fundamentals of flux dynamics and measurements of fine aerosol and gaseous species are essentially identical in the atmospheric surface layer. While there are differences for very large particles in terms of settling and differences in transport at the laminar sub-layer, these differences do not affect atmospheric surface layer flux measurements and calculations for fine aerosols. The raw fluxes $\left(F_{m / z}\right)$ for 10 selected aerosol $\mathrm{m} / \mathrm{z}$ (see Section 2.3) were calculated using the standard EC method as the cross product of the instantaneous deviation of the vertical wind velocity $\left(w^{\prime}\right)$ and the instantaneous deviation of each mass concentration $\left(\chi_{m / z}^{\prime}\right)$ from their 30-min means (McMillen, 1988):

$F_{m / z}=\overline{w^{\prime} \chi_{m / z}^{\prime}}=\frac{1}{N} \sum_{i=1}^{N} w^{\prime}\left(t_{i}\right) \chi_{m / z}^{\prime}\left(t_{i}\right)$

The same method was employed to calculate energy and gas fluxes measured at this site (Velasco et al., 2009, 2011) and during a previous Mexico City study at a different site (Velasco et al., 2005a, b).

The method to calculate the fluxes of aerosol components (nitrates, sulfates and organics), using only a few $\mathrm{m} / \mathrm{z}$ scanned in the flux mode was developed by Nemitz et al. (2008). After the raw equivalent mass concentrations $\left(\chi_{m / z}\right)$ (Zhang et al., 2005) and raw fluxes $\left(F_{m / z}\right)$ of the individual masses were calculated, the exchange velocity $V_{\text {ex } m / z}=F_{m / z} / \chi_{m / z}$ was determined for each $m / z$. The comparison of the $V_{\mathrm{ex} m / z}$ calculated for different $\mathrm{m} / \mathrm{z}$ derived from the same compound (e.g., $m / z, 48$ and 64 for $\mathrm{SO}_{4}^{2-}$ ) provides a strong quality control. Because the Q-AMS measures only a single $m / z$ at a time, the different $V_{\text {ex } m / z}$ reflect different particle populations and the comparison of related $V_{\mathrm{ex} m / z}$ provides information on the uncertainty associated with particle statistics. Above Mexico City there was a very strong correlation between related $V_{\mathrm{exm} / z}$ (Fig. S3). The sulfate and nitrate aerosol fluxes were then calculated using the total sulfate and nitrate concentration obtained from the MS mode and the subsequent period $V_{\mathrm{ex} m / z}$ from JMS mode. Ammonium fluxes typically cannot be determined with the Q-AMS due to high noise from the interference of $\mathrm{H}_{\mathrm{x}} \mathrm{O}^{+}$ions at the same $\mathrm{m} / \mathrm{z}$, and require the use of the high resolution AMS (Farmer et al., 2011).

The determination of fluxes of the organic components is more complex because different organic aerosol components can contribute to the signal for an individual $\mathrm{m} / \mathrm{z}$. These fractional contributions are estimated from the PMF analyses. In terms of aerosol fluxes, the flux of each $m / z\left(F_{m / z}\right)$ reflects a linear combination of the fluxes of the different OA compo- nents $\left(F_{i}\right.$, where $i=\mathrm{HOA}, \mathrm{OOA}$ and BBOA):

$F_{m / z}=\sum_{m / z} a_{m / z, i} \cdot F_{i}$

Here, $a_{m / z, i}$ is the fraction of a component's total signal represented by a particular $\mathrm{m} / \mathrm{z}$. Equation (2) can be inverted to provide a unique solution for three $F_{i}$ (i.e. $F_{\mathrm{HOA}}, F_{\mathrm{OOA}}$, and $\left.F_{\mathrm{BBOA}}\right)$ from the measured fluxes of three different $\mathrm{m} / \mathrm{z}$ $\left(F_{m / z}\right)($ Nemitz et al., 2008). In this study, the factors are derived from the ambient scan mode while fluxes are calculated from the flux jump mode. This approach assumes that the mass spectra of the concentration components are also representative of the flux components. In this analysis, we used four $m / z$ in a linear best-fit approach to determine the three organic aerosol factors, where the $\mathrm{m} / \mathrm{z}$ used were $31,43,55$ and 57.

To summarize, the fractional contributions of each $\mathrm{m} / \mathrm{z}$ to each organic component were obtained by PMF using the 30-min concentration measurement mode. The fluxes of individual organic mass elements were obtained from eddy covariance analyses using the flux mode data. The fractional contributions and the individual mass fluxes were used in a least-squared residual minimization of Eq. (2) to yield the final organic flux components for HOA, OOA, and BBOA. Because of the $\mathrm{m} / \mathrm{z}$ selected for flux mode measurements, decomposition of OOA fluxes into the volatility components was not included.

The remainder of the flux data reduction method was based on the approach described by Velasco et al. (2005a, b, 2009). During data reduction, raw data with low AMS sample flow rates were discarded; in total twelve 30-min periods were discarded, most of them on 14 March. Hard spikes and soft spikes in the sonic anemometer data were eliminated (Schmid et al., 2000). Hard spikes are random electronic spikes caused by a blocked path between a sonic anemometer sensor pair (e.g., from precipitation) and are flagged during the measurements (Vickers and Mahrt, 1997). About $0.05 \%$ of data points were removed from the data as hard spikes, approximately 10 points per period. Soft spikes are large shortlived departures from the 30-min period means; soft spikes were removed during post processing using a series of filters corresponding to $3.6,3.9$, and 4.2 times the standard deviation (Højstrup, 1993). About $1 \%$ of data points were removed as soft spikes.

For each 30-min flux mode measurement period, a coordinate rotation was applied to align the $u_{\mathrm{x}}$ wind component to the direction of the mean flow (Aubinet et al., 2000). Due to the travel time through the tubing from the top of the tower to the instrument, a lag time correction was also applied. The lag time was calculated by selecting the maximum in the cross-correlation spectrum of covariance as a function of time. The results showed relatively consistent time lags in the range of 4.7-5.5 s, and consistent with the estimated tubing flow time. Finally, Webb-Pearman-Leuning (WPL) corrections due to density fluctuations associated with water vapor 
fluctuations were applied (Webb et al., 1980) and a high frequency correction was applied to account for high frequency losses during transport down the sampling line. The WPL correction was insignificant, less than $0.1 \%$.

To evaluate the overall operation of the system, (co)spectral analyses were conducted, and the flux data were evaluated in terms of meteorological stationarity. The spectral and co-spectral analyses are important as the EC system tends to attenuate the true turbulent signal at high and low frequencies due to physical size limitations of the instruments, the instrument separation distances, and their time response and signal processing (Massman and Lee, 2002). The spectra showed a good agreement (slope approximately $-5 / 3$ ) for the temperature and the measured aerosol mass concentrations. Power co-spectra of instantaneous deviation of mass fluxes were also calculated (see example $\mathrm{m} / \mathrm{z} 43$, Fig. S4 in the Supplement). The co-spectral analysis showed a good agreement with previously reported results from $\mathrm{Ne}-$ mitz et al. (2008).

As described by Aubinet et al. (2000), a stationarity test helps to identify non-valid sampling periods affected by the short-term horizontal advection produced by local plumes or rapidly changing wind or stability conditions. The test was applied by examining the difference between the 30-min averaged flux and the average of six 5-min average fluxes measured in Flux mode. Each period was accepted if the two averages were within $60 \%$ of each other (Aubinet et al., 2000). $25 \%$ of the periods were excluded from the analysis based on this test (Fig. S5 in the Supplement).

It should be noted that with a single point flux measurement, errors due to storage and advection could not be quantified during this study. Moreover, the flux measurement cannot distinguish between primary emissions, chemical production, and condensation below the measurement height (for upward fluxes), or between deposition and evaporation below the measurement height (for downward fluxes). All fluxes reported here should therefore be considered local fluxes at the measurement height.

A footprint area indicates the size of the area that measured flux originates from. A source footprint analysis was performed using a simple footprint model (Hsieh et al., 2000). This model is a one-dimensional Lagrangian stochastic dispersion model, based on Gaussian turbulence. The footprint area that accounted for $80 \%$ of the measured aerosol flux extended from approximately 0.8 to $1.9 \mathrm{~km}$ (Fig. 1). The footprint of our measurements includes most of the major roads, highways, and intersections in the immediate area. Thus, our measurements appear to be representative of this heavily populated residential and commercial district of Mexico City.

\section{Results and discussion}

\subsection{Meteorological conditions and aerosol concentrations}

The dry season for central Mexico is from January until June. The MILAGRO field campaign was conducted during March to target dry, mostly sunny conditions representative of the dry season (Yokelson et al., 2007; Molina et al., 2010). Meteorological conditions during the measurement period were averaged to $30 \mathrm{~min}$ and are presented in Fig. 2. Temperatures were in the range of 15 to $30^{\circ} \mathrm{C}$, except in the last week when conditions cooled and several rainy days occurred. Wind speeds were low at night and in the range of 2 to $6 \mathrm{~m} \mathrm{~s}^{-1}$ during the daytime hours.

These meteorological conditions led to changes in wildfire intensity around Mexico City during March 2006. Aiken et al. (2010) divided the campaign into three distinct fire periods: 11-15, 17-23 and 24-29 March. The number of fires was high during the first and second periods and low during the third period (Fig. S2). Aiken et al. (2010) showed that at the $T_{0}$ site, a MILAGRO urban supersite located about $10 \mathrm{~km}$ north of the SIMAT flux tower (see Fig. 1 for location), nonfire related gas and particle species showed little change between the three periods, while levels of fire-related species were much lower during the 3rd period, compared with the first two periods. In general, the fire activity during March 2006 was about twice as high as the climatological average (Molina et al., 2010).

Time series of the 2.5-min average concentrations of chloride, ammonium, nitrate, sulfate, and organic aerosols in nonrefractory sub-micron particles measured in the MS submode are shown in Fig. 3 (for the statistics of the aerosol species, see Table 1). The time series of the aerosol concentrations show some similarities among different aerosol species. For example, peak concentrations among ammonium, nitrate, total organic aerosol (OA), and OOA occurred during 16 March and again several times during the last week of the measurement period. In the latter period, these peaks were also reflected by peaks in the $\mathrm{CO}_{2}$ and HOA concentrations.

The similarities and differences between compounds are more apparent in the diurnal average graphs in Fig. 4. The bars indicate the day-to-day variability (one standard deviation). Here, there are three separate diurnal patterns: (1) broad mid-day maxima with low concentrations at night for nitrate, OOA, and to a lesser extent $\mathrm{OA}$; (2) a morning rush hour maxima with lower levels during the rest of the day and night for HOA and chloride; and (3) somewhat more constant levels throughout the day and night for sulfate and BBOA (for a correlation analysis between all the species, see Table $\mathrm{S} 1$ in the Supplement). Ammonium is associated with both nitrate and sulfate and therefore shows the midday maximum of the nitrate, but larger nighttime concentrations due to the contribution from sulfate. The broad daytime peaks for 


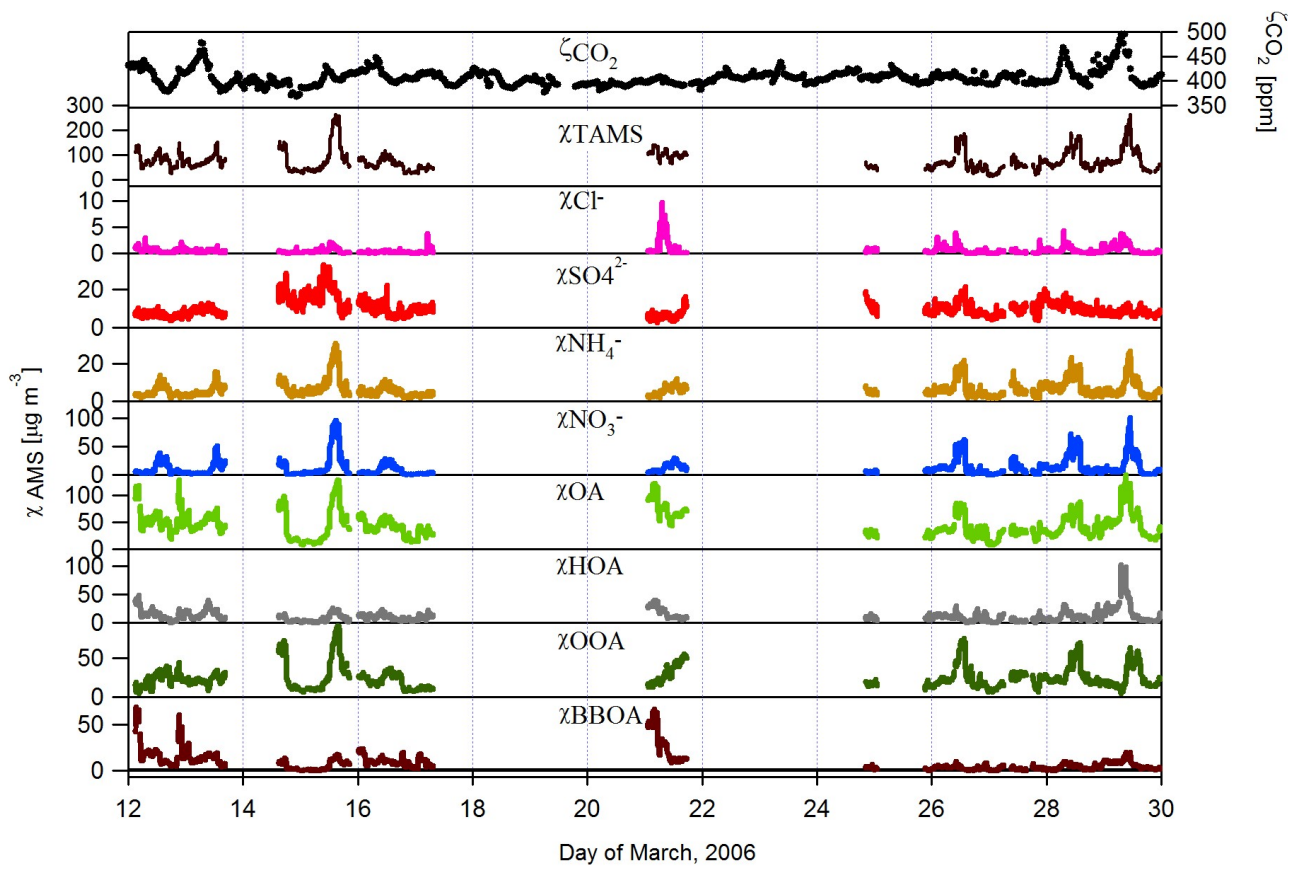

Fig. 3. Time series of $\mathrm{CO}_{2}$ mixing ratio $\left(\xi_{\mathrm{CO}_{2}}\right)$ (right axis) and mass concentrations $(\chi)$ of AMS non-refractory inorganic and organic aerosols (OA) components (left axes). Total non-refractory $\mathrm{PM}_{1}$ aerosols (black). Inorganic aerosols: chloride $\left(\mathrm{Cl}^{-}\right)\left(\right.$pink), sulfate $\left(\mathrm{SO}_{4}^{2-}\right)$ (red), ammonium $\left(\mathrm{NH}_{4}^{+}\right)$(orange), and nitrate $\left(\mathrm{NO}_{3}^{-}\right)$(blue). Organic aerosols $(\mathrm{OA})$ (green), hydrocarbon-like (HOA) (grey), oxygenated (OOA) (dark green), and biomass-burning (BBOA) (brown).

nitrate and OOA suggest photochemical processing of the urban air mass (Salcedo et al., 2006; Volkamer et al., 2006; Zheng et al., 2008; Paredes-Miranda et al., 2009). This is supported by the time lag in the diurnal peaks between $\mathrm{NO}$ at 07:00 and $\mathrm{NO}_{2}$ at 10:00 followed by the nitrate aerosol concentration peak at 13:30. Similarly, a 6-h time lag was present between the concentrations of olefins and OOA. We found a high correlation between the concentrations of nitrate and ammonium aerosols and OOA $(R=0.86)$. Similarly, Aiken et al. (2009) reported a good correlation $(R=0.71)$ between OOA and nitrate aerosol concentrations, following diurnal patterns of $\mathrm{CO}, \mathrm{CO}_{2}$ and $\mathrm{NO}$ and consistent with the similar atmospheric processing and formation rates of both OOA and nitrate aerosol (Dzepina et al., 2009). The sharp peak for HOA, coinciding with rush hours, reflects fresh, local emissions which is similar to the pattern for $\mathrm{CO}_{2}(R=0.90)$ associated with mobile and other urban activities (Velasco et al., 2009). The more constant concentrations of sulfate and BBOA suggest broad urban or regional air mass impacts, although there is some indication of a morning peak for sulfate that occurs after the rush hour peak in HOA, but before the mid-day peak in nitrate.

Based on the knowledge of different fire activity during the measurement period, the diurnal averages of aerosol concentration data for two week periods were calculated for: (1) high fire activity (12-17 March); and (2) low fire activity during the wetter cooler week (24-30 March). The diurnal pro-
Table 1. Concentration measurement statistics of urban aerosols. All the components in the table have $\mu \mathrm{g} \mathrm{m}^{-3}$ units and were computed from 2605 (2.5 min average) data points sampled during MS mode.

\begin{tabular}{lcccc}
\hline Concentration & Average & Minimum & Maximum & $\begin{array}{c}\text { Standard } \\
\text { deviation }\end{array}$ \\
\hline Nitrate & 13 & 0.4 & 101 & 15 \\
Sulfate & 10 & 2.6 & 33 & 4.2 \\
Ammonium & 6 & 1.4 & 31 & 4.3 \\
Chloride & 0.6 & 0 & 9.7 & 0.8 \\
OA & 46 & 7.9 & 142 & 25 \\
HOA & 13 & 0 & 102 & 13 \\
OOA & 24 & 4.3 & 91 & 14 \\
BBOA & 9 & 0 & 69 & 11 \\
PM1 AMS & 76 & 45 & 263 & 12 \\
\hline
\end{tabular}

files of all the species, except BBOA, displayed no difference in daily trends between the two periods. In contrast, the diurnal profiles of BBOA were very different (Fig. $4 \mathrm{~g}$ ) with much higher concentrations of BBOA during 12-17 March compared to the low fire period later in the month. During the cooler low fire activity week, the diurnal pattern of BBOA concentrations followed the trends of $\mathrm{HOA}$ and $\mathrm{CO}_{2}$, suggesting the influence or urban biomass burning or cooking sources during this period. However, during the high fire activity week the diurnal average concentrations peaked at 

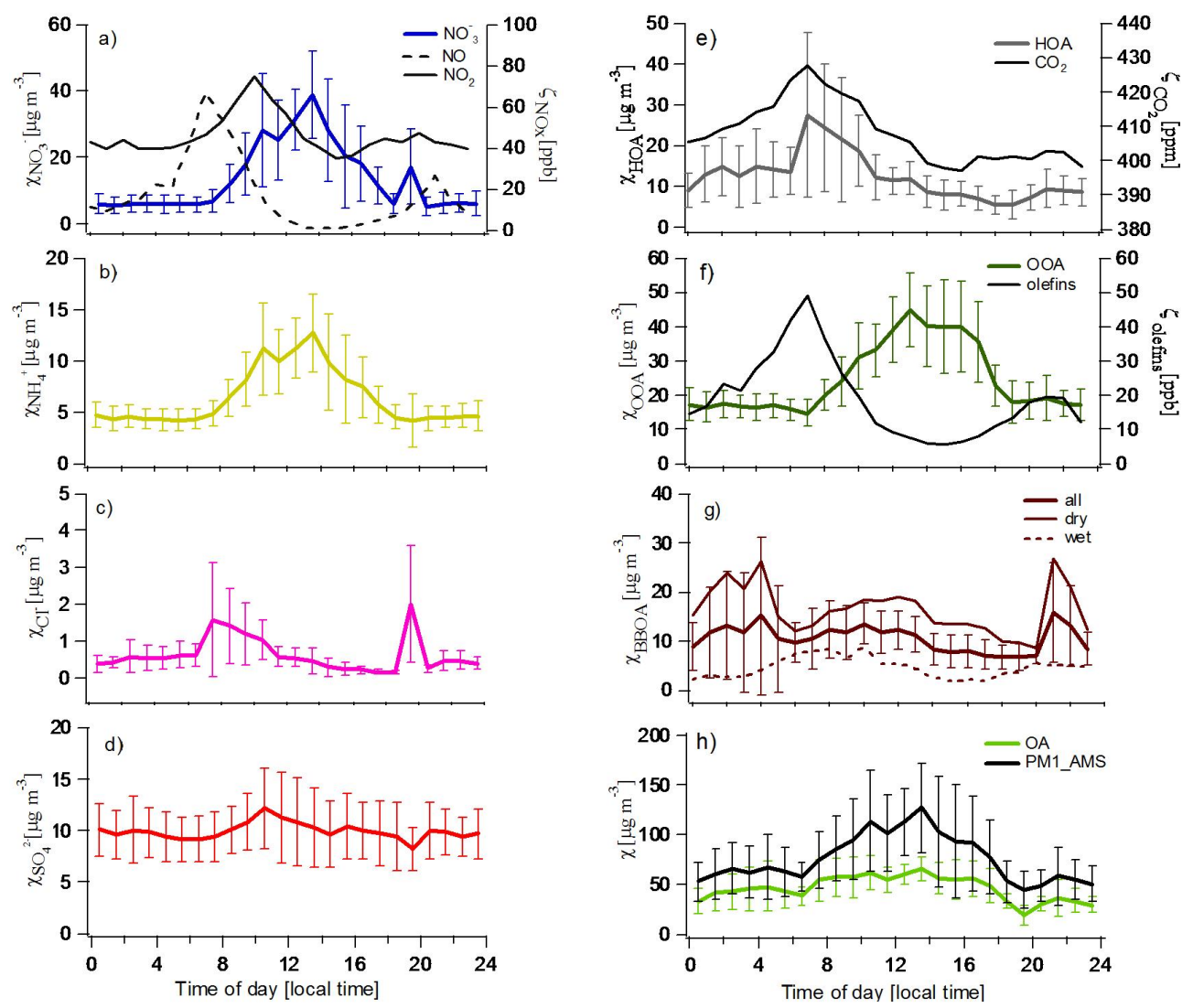

Fig. 4. Average diurnal patterns of ambient mixing ratios of trace gases and mass concentrations of AMS non-refractory submicron inorganic and organic aerosol components measured during the entire study. Bars indicate one standard deviation. (a) $\mathrm{NO}_{3}^{-}, \mathrm{NO}$, and $\mathrm{NO}_{2},(\mathbf{b}) \mathrm{NH}_{4}^{+}$, (c) $\mathrm{Cl}^{-}$, (d) $\mathrm{SO}_{4}^{2-}$ (e) $\mathrm{CO}_{2}$ and $\mathrm{HOA}$, (f) OOA and olefins, (g) BBOA during the dry week 12-17 March (thin solid line), wet week 24-30 March (thin broken line), and both weeks (brown line), and (h) OA (green line) and total non-refractory $\mathrm{PM}_{1}$ aerosols (black line).

night and during the very early morning, which could reflect nocturnal transport of biomass emissions into the central part of the city (Aiken et al., 2010). The overall elevated background concentrations indicate the regional origin of most BBOA during 12-18 March, consistent with wildfires being the dominant sources.

For the broad mid-day maximum pattern, average diurnal cycles peaked at $38 \mu \mathrm{g} \mathrm{m}^{-3}$ for nitrate, $12 \mu \mathrm{g} \mathrm{m}^{-3}$ for ammonium, and $45 \mu \mathrm{g} \mathrm{m}^{-3}$ for OOA. For HOA, the morning peak, presumably due to the morning rush hour, was $28 \mu \mathrm{g} \mathrm{m}^{-3}$ and for $\mathrm{Cl}^{-}$, the peak was less than $2 \mu \mathrm{g} \mathrm{m}^{-3}$. Sulfate levels averaged $10 \mu \mathrm{g} \mathrm{m}^{-3}$ with a late morning peak of $12 \mu \mathrm{g} \mathrm{m}^{-3}$, while BBOA averaged about $17 \mu \mathrm{g} \mathrm{m}^{-3}$ during the high fire period with nighttime maximum levels of $25 \mu \mathrm{g} \mathrm{m}^{-3}$ and much lower average concentrations of $4.6 \mu \mathrm{g} \mathrm{m}^{-3}$ and late morning peak of $8.5 \mu \mathrm{g} \mathrm{m}^{-3}$ during the low fire activity week.

Inorganic aerosol concentrations were larger at the SIMAT flux tower site, but followed similar diurnal variations as observed at the $T_{0}$ site (Aiken et al., 2009). In particular, nitrate and ammonium aerosol concentrations were larger by a factor of two at the tower site compared to $T_{0}$. This is attributed to higher concentrations of precursors $\left(\mathrm{NH}_{3}\right.$ and $\left.\mathrm{NO}_{\mathrm{x}}\right)$ at the central urban tower location, and the very rapid production of $\mathrm{HNO}_{3}$ observed in Mexico City (Zheng et al., 2008). The concentrations of sulfate aerosols were essentially constant and similar at both sites, consistent with the regional character of this species (Salcedo et al., 2006; DeCarlo et al., 2008). The average relative aerosol composition derived with the QAMS at SIMAT (Fig. S6) confirmed that submicron sulfate at SIMAT and $\mathrm{PM}_{2.5}$ sulfate at $T_{0}$ were occupying the same fraction.

During the measurement period, a few events were observed with peak concentrations of BBOA at about $60 \mu \mathrm{g} \mathrm{m}^{-3}$ (Fig. 3). These peaks of BBOA occurred during the early morning and late night of March 12 in the first fire period and during the early morning of March 21 . BBOA concentrations decreased substantially in the morning following BBOA events as the planetary boundary layer depth increased. The BBOA concentrations during the last week of March were lower with average concentrations of $4 \mu \mathrm{g} \mathrm{m}^{-3}$. These findings are consistent with Aiken et al. (2009) who identified the last week of March as the lowest fire activity period, and with the increased precipitation and associated aerosol removal during this period. 
Overall, the OA components at the SIMAT flux tower correlate well with components obtained from a three-factor PMF solution of the High-Resolution Time-of-Flight AMS measurements at $T_{0}$ (Aiken et al., 2009, see their Fig. 3). Our findings can also be compared with Teflon filter samples collected during consecutive 8-hour periods and analyzed using a Fourier Transform Infrared (FTIR) spectroscopy technique (Gilardoni et al., 2009). Gilardoni et al. (2009) estimated a $33 \%$ to $39 \%$ BBOA contribution to the OA at the SIMAT site using total potassium $\left(\mathrm{K}^{+}\right)$concentrations as a tracer. However, Aiken et al. (2010) showed that total $\mathrm{K}^{+}$was strongly influenced by sources other than biomass burning during MILAGRO, and estimated that BBOA estimates based on total $\mathrm{K}^{+}$may be overestimated by about a factor of two. This supports our findings, which indicate that $19 \%$ of OA was BBOA. Gilardoni et al. (2009) observed organic matter $(\mathrm{OM})$ concentrations of $3-35 \mu \mathrm{g} \mathrm{m}^{-3}$ from filter samples collected at roof level while we measured OA concentrations in the range of $14-45 \mu \mathrm{g} \mathrm{m}^{-3}$ via the AMS sampling at $25 \mathrm{~m}$ above the roof. Similar differences in concentration ranges between the two methods were also observed for similar measurements at the high altitude Altzomoni site, located $60 \mathrm{~km}$ southeast from Mexico City Metropolitan Area (MCMA). These differences may be due to differences in aerosol size cuts or other differences between the measurement methods and the sampling heights.

Wind rose time-of-day analyses showed that stronger winds were prevalent from the southeast during early afternoon and west-northwest during late afternoon and evening hours (Fig. S7). Higher concentrations of nitrate and ammonium aerosols were associated with winds from the northeast. HOA concentrations were well distributed, but a few higher readings occurred during northerly winds. High BBOA concentration events were associated with westerly flows in the direction of a few fires within $15 \mathrm{~km}$ (Fig. S2 in the Supplement) during the fire periods. Small increases in OOA and sulfate aerosol concentrations occurred during periods with winds from the northwest and northeast.

To summarize, nitrate aerosol concentrations averaged approximately $13 \mu \mathrm{g} \mathrm{m}^{-3}$ and ammonium aerosol concentrations averaged $6 \mu \mathrm{g} \mathrm{m}^{-3}$ and both exhibited strong mid-day maxima. Sulfate aerosol concentrations averaged approximately $10 \mu \mathrm{g} \mathrm{m}^{-3}$, but showed little diurnal pattern compared to the other aerosol components. Organic aerosol concentrations averaged approximately $46 \mu \mathrm{g} \mathrm{m}^{-3}$ and were comprised of HOA (27\%), OOA (53\%), and BBOA (20\%). HOA aerosol concentrations showed a sharp maximum during morning rush hour, while OOA aerosol concentrations showed a mid-day maximum. BBOA displayed different diurnal trends depending on wildfire activity. During the week of high fire activity the BBOA levels were four times higher, with elevated nighttime concentrations compared to concentration levels measured during the low fire period when the concentration followed anthropogenic activity patterns.
Table 2. Flux measurement statistics of urban aerosols. All the components in the table have $\mu \mathrm{g} \mathrm{m}^{-2} \mathrm{~s}^{-1}$ units and were computed from 170 (30 min average) data points sampled during JMS and MS mode.

\begin{tabular}{lcccc}
\hline Flux & Average & Minimum & Maximum & $\begin{array}{c}\text { Standard } \\
\text { deviation }\end{array}$ \\
\hline Nitrate & -0.02 & -2.7 & 3.5 & 0.5 \\
Sulfate & -0.01 & -0.2 & 0.3 & 0.1 \\
HOA & 0.1 & -0.1 & 2.6 & 0.2 \\
OOA & 0.03 & -4.2 & 0.4 & 0.3 \\
BBOA & -0.03 & -0.9 & 2.1 & 0.2 \\
\hline
\end{tabular}

\subsection{Aerosol fluxes}

Fluxes of submicron aerosol chemical components were highly variable during the measurement period. Figure 5 shows the time series of fluxes of sulfate, nitrate, and OA components (OOA, HOA, and BBOA), along with the fluxes of $\mathrm{CO}_{2}$ and sensible heat. Diurnal-averaged profiles of chemically resolved aerosol fluxes and $\mathrm{CO}_{2}$ are presented in Fig. 6, with bars indicating the standard deviation (for the statistics of the aerosol species, see Table 2).

$\mathrm{CO}_{2}$ capture by vegetation during daytime was assumed to be negligible due to the sparse biomass in the monitored neighborhood compared to the strong $\mathrm{CO}_{2}$ mobile source and other combustion sources. Fluxes of $\mathrm{CO}_{2}$ significantly increased in the morning, with maximum fluxes of $0.8 \mathrm{mg} \mathrm{m}^{-2} \mathrm{~s}^{-1}$, and decreased at night (Figs. 5 and 6). Similar trends were observed for HOA fluxes, reflecting the dominance of vehicular traffic emissions and associated early morning human activities (see Fig. 9a in Velasco et al., 2009). This result is consistent with previous studies based on concentrations (Aiken et al., 2009; DeCarlo et al., 2010) and fluxes (Thomas, 2007; Nemitz et al., 2008). Strong emissions of HOA were observed with the average diurnal cycle with maximum emissions of $0.19 \mu \mathrm{g} \mathrm{m}^{-2} \mathrm{~s}^{-1}$; this flux is larger than those measured in Boulder, Gothenburg, and Manchester. Overall, HOA fluxes were correlated with the diurnal trend of $\mathrm{CO}_{2}$ fluxes $(R=0.74)$ (Table $\mathrm{S} 2$ in the Supplement).

Fluxes of OOA were small and positive, approximately $0.03 \mu \mathrm{g} \mathrm{m}^{-2} \mathrm{~s}^{-1}$, which suggests that some SOA formation was occurring below the measurement height. In contrast, sulfate fluxes were extremely small, but on average exhibited some deposition during the morning. This is consistent with the AMS flux measurements above Boulder and European cities where low-sulfur fuels are used, and with the dominance of volcanoes and refineries/power plants elsewhere in Central Mexico on the sulfate budget (DeCarlo et al., 2008).

Fluxes of nitrate and BBOA were strongly correlated $\left(R^{2}=0.8\right.$, see Table $\mathrm{S} 2$ in the Supplement), both showing deposition on average during the day with a small positive (emission) peak in late afternoon. The deposition fluxes of $\mathrm{BBOA}$ are consistent with the fact that the dominant source 


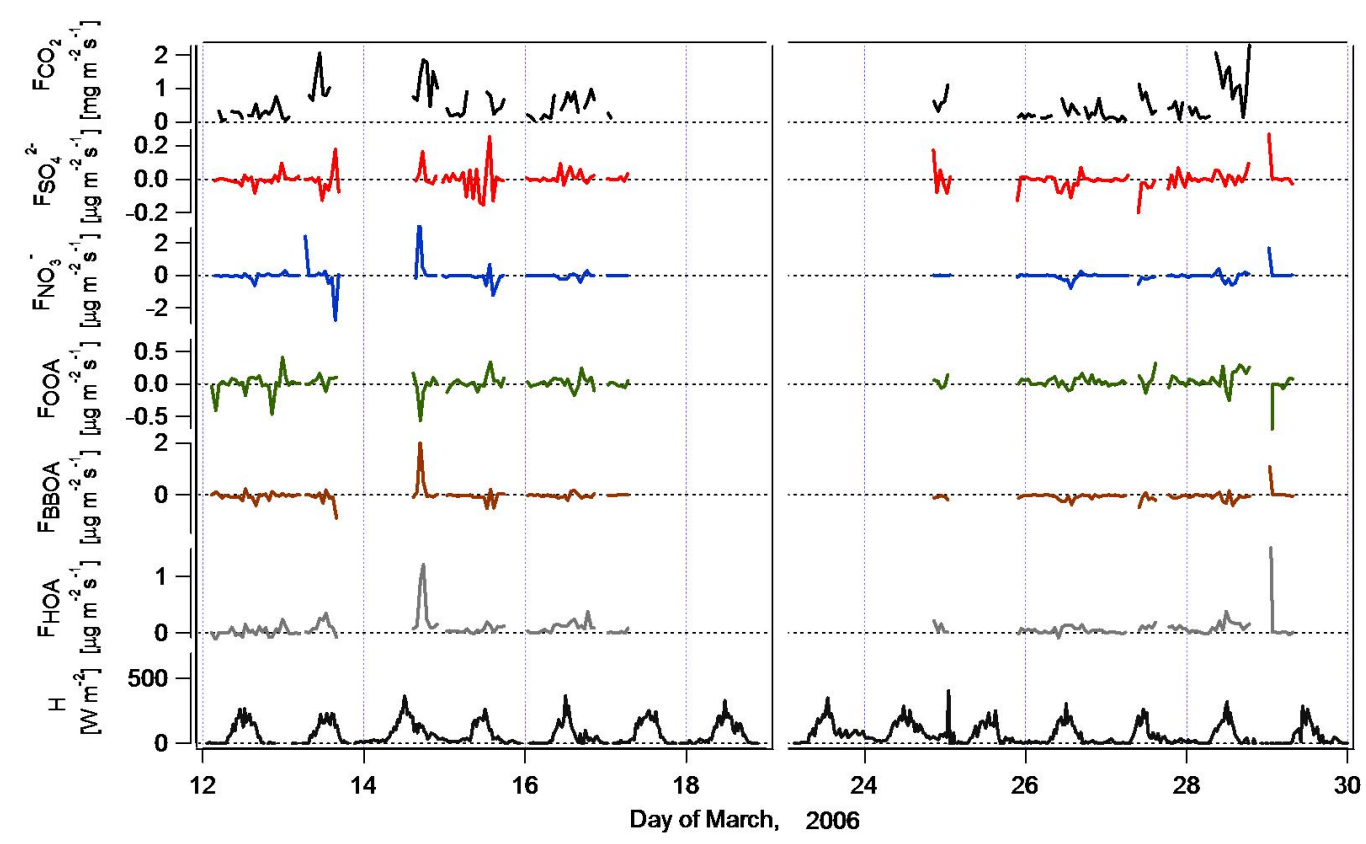

Fig. 5. Fluxes $(F)$ of $\mathrm{CO}_{2}$, sulfate aerosols $\left(\mathrm{SO}_{4}^{2-}\right)$, nitrate aerosols $\left(\mathrm{NO}_{3}^{-}\right)$, organic aerosol components $(\mathrm{OOA}$, BBOA, and $\mathrm{HOA})$, and sensible heat $(\mathrm{H})$ fluxes during the campaign.
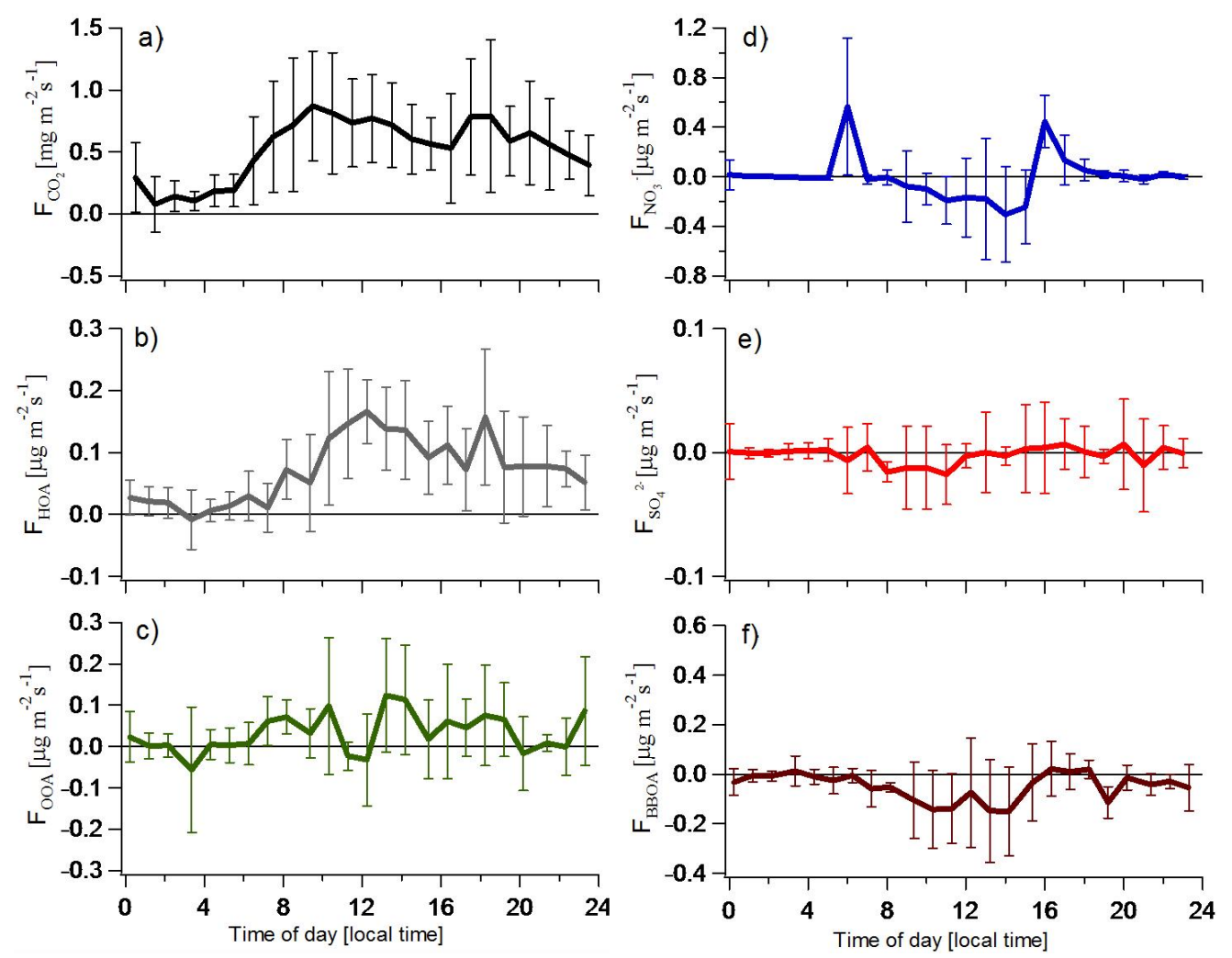

Fig. 6. Average diurnal patterns of fluxes of organic aerosol components and inorganic aerosols, and $\mathrm{CO}_{2}$ (a) measured during the entire study. Aerosol component fluxes identified in this study were (b) HOA, (c) OOA, (d) nitrate, (e) sulfate, and (f) BBOA. Bars indicate one standard deviation. 

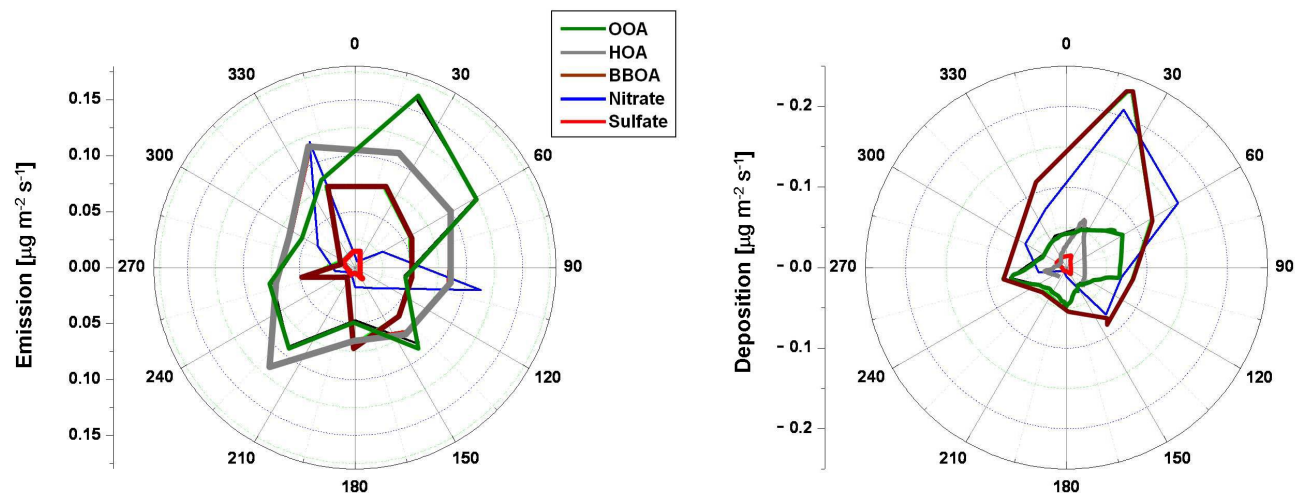

Fig. 7. Magnitude of nitrate, sulfate, and organic aerosol component fluxes as a function of the upwind direction.

of BBOA during this period was probably wildfires outside of Mexico City (Aiken et al., 2010; DeCarlo et al., 2010). Notably, while the trend and concentrations of BBOA were significantly different during the two high-fire activity periods, the BBOA fluxes did not display much difference in diurnal trends between these two periods. During the field campaign, deposition of BBOA was observed during the day at about $-0.16 \mu \mathrm{g} \mathrm{m}^{-2} \mathrm{~s}^{-1}$. This is the first time that BBOA fluxes have been identified in isolation in an urban AMS flux study. Average nitrate fluxes were small over Edinburgh and Manchester, while significant upward fluxes were observed at the higher measurement heights in Gothenburg (in winter) and London (in autumn) with large day-to-day variability (Thomas, 2007). In contrast, above Mexico City, significant downward fluxes of nitrate were observed, with a maximum deposition in the average diurnal cycle of $-0.3 \mu \mathrm{g} \mathrm{m}^{-2} \mathrm{~s}^{-1}$. The causes of the observed deposition may be due to atmospheric dynamics associated with mixing of urban scale nitrate downward into the warmer urban canopy where it can be volatilized or scavenged. The net drivers for volatilization are the gradients of the concentrations of precursor gases in equilibrium with $\mathrm{NH}_{4} \mathrm{NO}_{3}$ (i.e., $\mathrm{NH}_{3}$ and $\mathrm{HNO}_{3}$ ) and the gradients in temperature and relative humidity, which determine the equilibrium vapor pressures of the gas-phase precursors. It appears that in Mexico City, $\mathrm{NH}_{4} \mathrm{NO}_{3}$ evaporation below the measurement height contributed to the downward fluxes. This could be driven by temperature gradients associated with sensible heat fluxes (Figs. 2 and 5) that were larger than those in the European cities. However, further gradient profile and flux measurements of $\mathrm{NH}_{3}$ and $\mathrm{HNO}_{3}$ would be required to confirm this.

Previous studies from MILAGRO have established that the urban area is the dominant source of nitrate, while the forest fires are a very minor source (DeCarlo et al., 2008). Both the BBOA and nitrate aerosols displayed a small positive emission flux during late afternoon (indicative of formation below the measurement height being proportionally more important during those periods). However, due to the high day-to-day variability in the BBOA flux, it implies that these evening emissions were likely isolated events, possibly attributed to cooking. Evening nitrate emissions were present during most of the evenings.

Approximately $80 \%$ of HOA, $60 \%$ of OOA, and $30 \%$ of individual BBOA flux data points were positive (Fig. S8 in the Supplement). Overall, during the campaign, $47 \%$ of the apparent organic emissions were HOA, $35 \%$ were OOA, and $18 \%$ were BBOA. The deposition of organic particulate material was strongly dominated by the BBOA $(54 \%)$.

Depending on their sign, fluxes were separated into emissions or deposition. Figure 7 shows the magnitude of sulfate, nitrate and organic aerosol component fluxes as a function of the upwind direction. This type of analysis must be interpreted with care, due to the strong correlation of wind direction with time of the day. Sulfate aerosol fluxes, both emission and deposition, were small and independent of wind direction. Spikes in nitrate emission were observed only with the flows from northwest and east directions, and these spikes occurred during instances of high wind speed during the campaign (Fig. 5). This could suggest that some spikes are storage/venting events associated with changes in concentrations related to changes in air mass. BBOA fluxes were evenly distributed for winds from the east, but showed more variability for west winds (night and early morning wind flows) (Fig. S9 in the Supplement). HOA emissions had the most uniform distribution independent of the wind direction, with peaks correlated with winds from the southwest, where the intersection of a few major highways was located. OOA emissions occurred in a spatial pattern similar to HOA emissions, while deposition of nitrate, BBOA and OOA aerosols were predominately associated with northeasterly flows (Fig. 7).

\subsection{Evaluation of the local gridded emissions inventory of $\mathbf{P M}_{2.5}$}

An important purpose of the EC flux measurements of pollutant gases and aerosols during MILAGRO was to aid in the evaluation of the local emissions inventory. The inventory 
is based on bottom-up methods and emission factors, which were either measured locally or taken from the literature. It covers the entire metropolitan area in cells of $1 \mathrm{~km}^{2}$, with hourly mass emissions of $\mathrm{PM}_{2.5}$ and other pollutants from mobile, area, and point sources, using 2006 base data (SMAGDF, 2008). The inventory accounts for primary particles such as black carbon (BC), primary organic aerosol (POA), dust, and metals, but does not provide speciated information. Our comparison between the EC fluxes and the local emission inventory is thus complicated by the imperfect overlap between the AMS measurements and the emission inventory with respect to particle size cut-off $\left(\mathrm{PM}_{1}\right.$ vs. $\left.\mathrm{PM}_{2.5}\right)$ and the chemical components tracked (HOA vs. total particulate mass). To make a comparison, we first estimated the fraction of the inventory due to $\mathrm{PM}_{1}$ emissions ( $80 \%$ of $\mathrm{PM}_{2.5}$ ) and second, we assumed the contribution of black carbon (BC) was $75 \%$ of the measured HOA flux. Querol et al. (2008) estimated that about $80 \%$ of $\mathrm{PM}_{2.5}$ consists of $\mathrm{PM}_{1}$ at $T_{0}$, while Moya et al. (2011) reached the same conclusion for the $\mathrm{T}_{1}$ suburban site during MILAGRO, as did Salcedo et al. (2006) for a different urban site in a previous study. Aiken et al. (2009) reported that BC was approximately $75 \%$ of the HOA contribution (see their Figure 5a) and, thus, we estimate BC as $75 \%$ of our measured HOA fluxes. With these two assumptions, we can compare our measured $\mathrm{PM}_{1}$ fluxes of HOA plus the derived $\mathrm{BC}$ emission with the derived $\mathrm{PM}_{1}$ mass emissions from the inventory. The use of the measured fluxes may lead to an underestimate of the real emissions, as the deposition of some of the airborne material may partially cancel the local emissions, resulting in a smaller local net flux.

Figure 8 shows the daily averaged profiles of the sum of measured HOA fluxes and estimated BC fluxes, and compares those with the estimated $\mathrm{PM}_{1}$ emissions from the emissions inventory for the grid cells corresponding to the observed footprint at the SIMAT flux tower and $T_{0}$ sites. The gray-shaded area indicates the standard deviation-based upper and lower limits for the measured data. Overall, the mass emission rates for the flux measurements (including estimated $\mathrm{BC}$ ) are in good agreement with the emission rate for the area around the tower in the emission inventory. The estimated $\mathrm{PM}_{1}$ emissions from the emissions inventory for the monitored footprint yield an average emission of $0.16 \mu \mathrm{g} \mathrm{m}^{-2} \mathrm{~s}^{-1}$, compared to the observed average $\mathrm{PM}_{1}$ fluxes of $0.15 \mu \mathrm{g} \mathrm{m}^{-2} \mathrm{~s}^{-1}$. However, it is important to recognize that the inventory emission rate includes dust and metal contributions, and thus it appears that the inventory underestimates the emissions of organic and black carbon aerosols as derived from the flux measurements. The degree to which this underestimate occurs cannot be determined from this comparison. Further, the temporal pattern in the inventory shows a sharp increase in emissions early in the morning, missing in our flux measurements, which suggests that the temporal profile used in the inventory overestimates the timing and magnitude of early morning emissions.

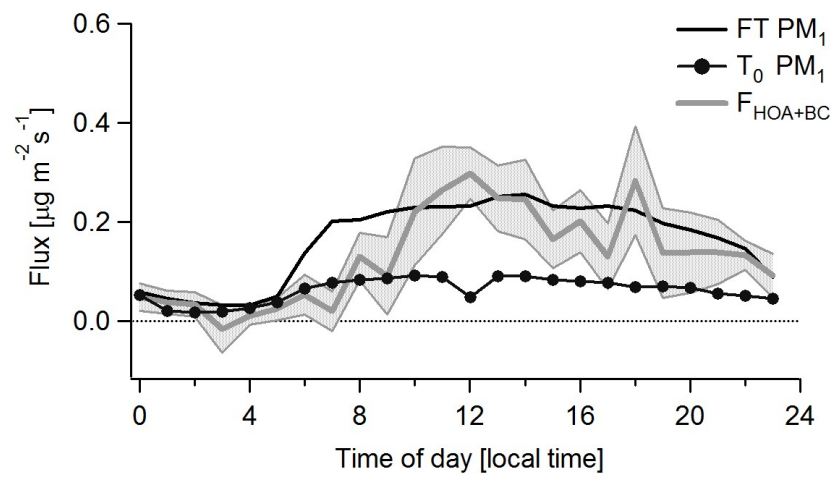

Fig. 8. Comparison of the diurnal profiles of non-refractory $\mathrm{PM}_{1}$ fluxes $(\mathrm{HOA}+\mathrm{BC})$ of primary aerosols (grey solid line, shaded area is \pm one standard deviation) with the diurnal profiles of $\mathrm{PM}_{1}$ emissions extracted and estimated from the 2006 official emissions inventory for the monitored footprint at the SIMAT flux tower site (black solid line) and the $T_{0}$ supersite (black solid line with markers). $\mathrm{PM}_{1}$ emissions were estimated as $80 \%$ of $\mathrm{PM}_{2.5}$.

Aiken et al. (2009) using measured ratios of $\mathrm{PM}_{2.5}$ to $\mathrm{CO}$ at the T0 site concluded that the inventory was low by as much as a factor of four, and Zavala et al. (2009) also found that the emission factors used for inventories were too low based on their on-road measurements. Our results also suggest that the inventory is low, although we cannot estimate the degree of this error from our results.

\section{Conclusions}

As part of the Megacity Initiative: Local and Global Research Observations (MILAGRO) 2006 field campaign, we measured the fluxes (positive emission fluxes and negative deposition fluxes) of organic and inorganic submicron aerosol chemical components using an eddy-covariance system based on an Aerosol Mass Spectrometer (AMS). The findings were compared with the official emissions inventory for the year 2006. These results are the first measured aerosol component mass fluxes for an arid, subtropical megacity. With the increasing number of megacities throughout the world, it is becoming increasingly necessary to characterize the particulate emissions in densely populated urban areas. This work demonstrates a powerful approach to directly quantify the near-surface fluxes of an important subset of particulate emissions- non-refractory $\mathrm{PM}_{1}$. While incomplete in terms of the range of PM species measured, this approach could provide a useful validation for the emissions inventories that are being implemented for these developing megacities.

The formation of sulfate aerosol from $\mathrm{SO}_{2}$ emissions is slow and there does not appear to be an emission of particulate sulfur from traffic sources in Mexico City. However the urban area does emit a substantial amount of organic aerosol. The diurnal pattern of concentrations and fluxes of 
hydrocarbon-like organic aerosol (HOA) in the center of Mexico City follows the diurnal patterns of $\mathrm{CO}_{2}$, suggesting vehicular traffic as the main emission source. Secondary organic aerosol, identified by the AMS as oxidized organic aerosol (OOA), also showed net emission, suggesting that OOA formation below the measurement height due to photochemical processing exceeded the deposition from SOA formed aloft and the regional background. Overall, $47 \%$ of organic emissions are HOA, $35 \%$ are OOA, and $18 \%$ are BBOA. BBOA deposition to the urban canopy occurs during the mid-day and the source of these aerosols was found to be associated with the wildfire activity surrounding Mexico City, based on concentration trends during the high fire activity period. Recurring nitrate aerosol emissions were observed only during evening rush hours with peak levels of $0.4 \mu \mathrm{g} \mathrm{m}^{-2} \mathrm{~s}^{-1}$. Otherwise, nitrate deposition was observed, possibly reflecting $\mathrm{NH}_{4} \mathrm{NO}_{3}$ evaporation in the warm urban canopy. This has not been observed in more northern cities where similar flux measurements have been completed. Comparison of the subset of the particulate Mexico City 2006 emissions inventory for the SIMAT flux tower site showed that the average fluxes of HOA and estimated BC were essentially the same as the estimated $\mathrm{PM}_{1}$ portion of the emission inventory. Since the inventory includes dust and metals while the observations do not, this quantitative match suggests that the inventory may in fact be underestimating the total PM emissions. These results may be biased due to the short length of the measurement period, and apply only for the measurement location.

\section{Supplementary material related to this article is available online at: http://www.atmos-chem-phys.net/12/ 7809/2012/acp-12-7809-2012-supplement.pdf.}

Acknowledgements. The Quadrupole Aerosol Mass Spectrometer was provided through a grant from the Environmental Molecular Sciences Laboratory (EMSL), a national scientific user facility sponsored by the Department of Energy's Office of Biological and Environmental Research located at Pacific Northwest National Laboratory. Funding for the field program and data analysis was provided by the US National Science Foundation (ATM-0528227), including Research Experience for Undergraduate funds. Ingrid M. Ulbrich and Jose L. Jimenez (University of Colorado, Boulder, CO) were supported by DOE (BER/ASR Program DE-SC0006035). The contribution from Eiko Nemitz was funded by the UK Natural Environment Research Council (NERC) through the grants "CityFlux" and "DIASPORA". The assistance and logistical support provided by the Atmospheric Monitoring System of the Federal District Government (SIMAT) was instrumental for the successful completion of this study.

Edited by: A. Baklanov

\section{References}

Aiken, A. C., Salcedo, D., Cubison, M. J., Huffman, J. A., DeCarlo, P. F., Ulbrich, I. M., Docherty, K. S., Sueper, D., Kimmel, J. R., Worsnop, D. R., Trimborn, A., Northway, M., Stone, E. A., Schauer, J. J., Volkamer, R. M., Fortner, E., de Foy, B., Wang, J., Laskin, A., Shutthanandan, V., Zheng, J., Zhang, R., Gaffney, J., Marley, N. A., Paredes-Miranda, G., Arnott, W. P., Molina, L. T., Sosa, G., and Jimenez, J. L.: Mexico City aerosol analysis during MILAGRO using high resolution aerosol mass spectrometry at the urban supersite (T0) - Part 1: Fine particle composition and organic source apportionment, Atmos. Chem. Phys., 9, 6633-6653, doi:10.5194/acp-9-6633-2009, 2009.

Aiken, A. C., de Foy, B., Wiedinmyer, C., DeCarlo, P. F., Ulbrich, I. M., Wehrli, M. N., Szidat, S., Prevot, A. S. H., Noda, J., Wacker, L., Volkamer, R., Fortner, E., Wang, J., Laskin, A., Shutthanandan, V., Zheng, J., Zhang, R., Paredes-Miranda, G., Arnott, W. P., Molina, L. T., Sosa, G., Querol, X., and Jimenez, J. L.: Mexico city aerosol analysis during MILAGRO using high resolution aerosol mass spectrometry at the urban supersite (T0) Part 2: Analysis of the biomass burning contribution and the non-fossil carbon fraction, Atmos. Chem. Phys., 10, 5315-5341, doi:10.5194/acp-10-5315-2010, 2010.

Allan, J. D., Coe, H., Bower, K. N., Alfarra, M. R., Delia, A. E., Jimenez, J. L., Middlebrook, A. M., Drewnick, F., Onasch, T. B., Canagaratna, M. R., Jayne, J. T., and Worsnop, D. R.: Technical note: Extraction of chemically resolved mass spectra from Aerodyne aerosol mass spectrometer data, J. Aerosol Sci., 35, 909-922, 2004.

Allan, J. D., Williams, P. I., Morgan, W. T., Martin, C. L., Flynn, M. J., Lee, J., Nemitz, E., Phillips, G. J., Gallagher, M. W., and Coe, H.: Contributions from transport, solid fuel burning and cooking to primary organic aerosols in two UK cities, Atmos. Chem. Phys., 10, 647-668, doi:10.5194/acp-10-647-2010, 2010.

Aubinet, M., Grelle, A., Ibrom, A., Rannik, U., Moncrieff, J., Foken, T., Kowalski, A. S., Martin, P. H., Berbigier, P., Bernhofer, C., Clement, R., Elbers, J., Granier, A., Grunwald, T., Morgenstern, K., Pilegaard, K., Rebmann, C., Snijders, W., Valentini, R., and Vesala, T.: Estimates of the Annual Net Carbon and Water Exchange of Forests: The EUROFLUX Methodology, Adv. Ecol. Res., 30, 113-175, 2000.

Canagaratna, M. R., Jayne, J. T., Jimenez, J. L., Allan, J. D., Alfarra, M. R., Zhang, Q., Onasch, T. B., Drewnick, F., Coe, H., Middlebrook, A. M., Delia, A. E., Williams, L. R., Trimborn, A. M., Northway, M. J., DeCarlo, P. F., Kolb, C. E., Davidovits, P., and Worsnop, D. R.: Chemical and Microphysical Characterization of Ambient Aerosols with the Aerodyne Aerosol Mass Spectrometer, Mass Spectrom. Rev., 26, 185-222, 2007.

Cappa, C. D. and Jimenez, J. L.: Quantitative Estimates of the Volatility of Ambient Organic Aerosol, Atmos. Chem. Phys., 10, 5409-5424, doi:10.5194/acp-10-5409-2010, 2010.

Crosier, J., Jimenez, J. L., Allan, J. D., Bower, K. N., Williams, P. I., Alfarra, M. R., Canagaratna, M. R., Jayne, J. T., Worsnop, D. R., and Coe, H.: Technical Note: Description and use of the new Jump Mass Spectrum mode of operation for the Aerodyne Quadrupole Aerosol Mass Spectrometers (Q-AMS), Aerosol Sci. Technol., 41, 865-872, 2007.

DeCarlo, P. F., Dunlea, E. J., Kimmel, J. R., Aiken, A. C., Sueper, D., Crounse, J., Wennberg, P. O., Emmons, L., Shinozuka, Y., Clarke, A., Zhou, J., Tomlinson, J., Collins, D., Knapp, D., Wein- 
heimer, A., Campos, T., and Jimenez, J. L.: Fast airborne aerosol size and chemistry measurements above Mexico City and Central Mexico during the MILAGRO campaign, Atmos. Chem. Phys., 4027-4048, doi:10.5194/acp-8-4027-2008, 2008.

DeCarlo, P. F., Ulbrich, I. M., Crounse, J., de Foy, B., Dunlea, E. J., Aiken, A. C., Knapp, D., Weinheimer, A. J., Campos, T., Wennberg, P. O., and Jimenez, J. L.: Investigation of the sources and processing of organic aerosol over the Central Mexican Plateau from aircraft measurements during MILAGRO, Atmos. Chem. Phys., 10, 5257-5280, doi:10.5194/acp-10-52572010, 2010.

Dorsey, J. R., Nemitz, E. G., Gallagher, M. W., Fowler, D., Williams, P. I., Bower, K. N., and Beswick, K. M.: Direct measurements and parameterisation of aerosol flux, concentration and emission velocity above a city, Atmos. Environ., 36 791800, 2002.

Dzepina, K., Volkamer, R. M., Madronich, S., Tulet, P., Ulbrich, I. M., Zhang, Q., Cappa, C. D., Ziemann, P. J., and Jimenez, J. L.: Evaluation of recently-proposed secondary organic aerosol models for a case study in Mexico City, Atmos. Chem. Phys., 9, 5681-5709, doi:10.5194/acp-9-5681-2009, 2009.

Farmer, D. K., Matsunaga, A., Docherty, K. S., Surratt, J. D., Seinfeld, J. H., Ziemann, P. J., and Jimenez, J. L.: Response of an Aerosol Mass Spectrometer to Organonitrates and Organosulfates and implications for Atmospheric Chemistry, Proc. Natl. Acad. Sci. USA, 107, 6670-6675, 2010.

Farmer, D. K., Kimmel, J. R., Phillips, G., Docherty, K. S., Worsnop, D. R., Sueper, D., Nemitz, E., and Jimenez, J. L.: Eddy covariance measurements with high-resolution time-offlight aerosol mass spectrometry: a new approach to chemically resolved aerosol fluxes, Atmos. Meas. Tech., 4, 1275-1289, doi:10.5194/amt-4-1275-2011, 2011.

Fast, J. D., de Foy, B., Acevedo Rosas, F., Caetano, E., Carmichael, G., Emmons, L., McKenna, D., Mena, M., Skamarock, W., Tie, X., Coulter, R. L., Barnard, J. C., Wiedinmyer, C., and Madronich, S.: A meteorological overview of the MILAGRO field campaigns, Atmos. Chem. Phys., 7, 2233-2257, doi:10.5194/acp-7-2233-2007, 2007.

Forster, P., Ramaswamy, V., Artaxo, P., Berntsen, T., Betts, R., Fahey, D. W., Haywood, J., Lean, J., Lowe, D. C., Myhre, G., Nganga, J., Prinn, R., Raga, G., Schulz, M., and Van Dorland, R.: Changes in Atmospheric Constituents and in Radiative Forcing, in: "Climate Change 2007: The Physical Science Basis. Contribution of Working Group I to the Fourth Assessment Report of the Intergovernmental Panel on Climate Change", Cambridge University Press, Cambridge, UK and New York, NY, USA, 2007.

Gilardoni, S., Liu, S., Takahama, S., Russell, L. M., Allan, J. D., Steinbrecher, R., Jimenez, J. L., De Carlo, P. F., Dunlea, E. J., and Baumgardner, D.: Characterization of organic ambient aerosol during MIRAGE 2006 on three platforms, Atmos. Chem. Phys., 9, 5417-5432, doi:10.5194/acp-9-5417-2009, 2009.

Heintzenberg, J.: Fine Particles in the Global Troposphere: A Review, Tellus B, 41, 149-160, 1989.

Højstrup, J.: A statistical data screening procedure, Meas. Sci. Technol., 4, 153-157, 1993.

Hsieh, C. I., Katul, G., and Chi, T.: An approximate analytical model for footprint estimation of scalar fluxes in thermally stratified atmospheric flows, Adv. Water Resour., 23, 765-772, 2000.
Jayne, J. T., Leard, D. C., Zhang, X. F., Davidovits, P., Smith, K. A., Kolb, C. E., and Worsnop, D. R.: Development of an aerosol mass spectrometer for size and composition analysis of submicron particles, Aerosol Sci. Technol., 33, 49-70, 2000.

Jimenez, J. L., Jayne, J. T., Shi, Q., Kolb, C. E., Worsnop, D. R., Yourshaw, I., Seinfeld, J. H., Flagan, R. C., Zhang, X., Smith, K. A., Morris, J., and Davidovits, P.: Ambient Aerosol Sampling with an Aerosol Mass Spectrometer, J. Geophys. Res.-Atmos., 108, 8425, doi:10.1029/2001JD001213, 2003.

Jimenez, J. L., Canagaratna, M. R., Donahue, N. M., Prevot, A. S., Zhang, Q., Kroll, J. H., DeCarlo, P. F., Allan, J. D., Coe, H., Ng, N. L., Aiken, A. C., Docherty, K. S., Ulbrich, I. M., Grieshop, A. P., Robinson, A. L., Duplissy, J., Smith, J. D., Wilson, K. R., Lanz, V. A., Hueglin, C., Sun, Y. L., Tian, J., Laaksonen, A., Raatikainen, T., Rautiainen, J., Vaattovaara, P., Ehn, M., Kulmala, M., Tomlinson, J. M., Collins, D. R., Cubison, M. J., Dunlea, E. J., Huffman, J. A., Onasch, T. B., Alfarra, M. R., Williams, P. I., Bower, K., Kondo, Y., Schneider, J., Drewnick, F., Borrmann, S., Weimer, S., Demerjian, K., Salcedo, D., Cottrell, L., Griffin, R., Takami, A., Miyoshi, T., Hatakeyama, S., Shimono, A., Sun, J. Y., Zhang, Y. M., Dzepina, K., Kimmel, J. R., Sueper, D., Jayne, J. T., Herndon, S. C., Trimborn, A. M., Williams, L. R., Wood, E. C., Middlebrook, A. M., Kolb, C. E., Baltensperger, U., and Worsnop, D. R.: Evolution of organic aerosols in the atmosphere, Science, 326, 1525-1529, 2009.

Lawrence, M. G., Butler, T. M., Steinkamp, J., Gurjar, B. R., and Lelieveld, J.: Regional pollution potentials of megacities and other major population centers, Atmos. Chem. Phys., 7, 39693987, doi:10.5194/acp-7-3969-2007, 2007.

Massman, W. J. and Lee, X.: Eddy covariance flux corrections and uncertainties in long-term studies of carbon and energy exchanges, Agr. Forest Meteorol., 113, 121-144, 2002.

McMillen, R.: An eddy correlation technique with extended applicability to non-simple terrain, Bound.-Layer Meteorol., 43, 231245, 1988.

Molina, L. T., Madronich, S., Gaffney, J. S., Apel, E., de Foy, B., Fast, J., Ferrare, R., Herndon, S., Jimenez, J. L., Lamb, B., Osornio-Vargas, A. R., Russell, P., Schauer, J. J., Stevens, P. S., Volkamer, R., and Zavala, M.: An overview of the MILAGRO 2006 Campaign: Mexico City emissions and their transport and transformation, Atmos. Chem. Phys., 10, 8697-8760, doi:10.5194/acp-10-8697-2010, 2010.

Moya, M., Madronich, S., Retama, A., Weber, R., Baumann, K., Nenes, A., Castillejos, M., and Ponce de León, C.: Identification of chemistry-dependent artifacts on gravimetric PM fine readings at the T1 site during the MILAGRO field campaign, Atmos. Environ., 45, 244-252, 2011.

Nemitz, E., Jimenez, J. L., Huffman, J. A., Canagaratna, M. R., Worsnop, D. R., and Guenther, A. B.: An eddy-covariance system for the measurement of surface/atmosphere exchange fluxes of submicron aerosol chemical species - first application above an urban area, Aerosol Sci. Technol., 42, 636-657, 2008.

Ng, N. L., Canagaratna, M. R., Zhang, Q., Jimenez, J. L., Tian, J., Ulbrich, I. M., Kroll, J. H., Docherty, K. S., Chhabra, P. S., Bahreini, R., Murphy, S. M., Seinfeld, J. H., Hildebrandt, L., Donahue, N. M., DeCarlo, P. F., Lanz, V. A., Prévôt, A. S. H., Dinar, E., Rudich, Y., and Worsnop, D. R.: Organic aerosol components observed in Northern Hemispheric datasets from Aerosol Mass Spectrometry, Atmos. Chem. Phys., 10, 4625- 
4641, doi:10.5194/acp-10-4625-2010, 2010.

Ng, N. L., Canagaratna, M. R., Jimenez, J. L., Zhang, Q., Ulbrich, I. M., and Worsnop, D. R.: Real-Time Methods for Estimating Organic Component Mass Concentrations from Aerosol Mass Spectrometer Data, Environ. Sci. Technol., 45, 910-916, 2011.

Paatero, P.: Least squares formulation of robust non-negative factor analysis, Chemometr. Int. Lab. Syst., 37, 23-35, 1997.

Paatero, P.: User's guide for positive matrix factorization programs PMF2.EXE and PMF3.EXE. University of Helsinki, Finland, 2007.

Paatero, P. and Tapper, U.: Positive matrix factorization - a nonnegative factor model with optimal utilization of error-estimates of data values, Environmetrics, 5, 111-126, 1994.

Paredes-Miranda, G., Arnott, W. P., Jimenez, J. L., Aiken, A. C., Gaffney, J. S., and Marley, N. A.: Primary and secondary contributions to aerosol light scattering and absorption in Mexico City during the MILAGRO 2006 campaign, Atmos. Chem. Phys., 9, 3721-3730, doi:10.5194/acp-9-3721-2009, 2009.

Pope III, C. A. and Dockery, D. W.: Health effects of fine particulate air pollution: lines that connect, J. Air Waste Manage. Assoc., 56, 709-742, 2006.

Querol, X., Pey, J., Minguillón, M. C., Pérez, N., Alastuey, A., Viana, M., Moreno, T., Bernabé, R. M., Blanco, S., Cárdenas, B., Vega, E., Sosa, G., Escalona, S., Ruiz, H., and Artíñano, B.: PM speciation and sources in Mexico during the MILAGRO-2006 Campaign, Atmos. Chem. Phys., 8, 111-128, doi:10.5194/acp8-111-2008, 2008.

Salcedo, D., Onasch, T. B., Dzepina, K., Canagaratna, M. R., Zhang, Q., Huffman, J. A., DeCarlo, P. F., Jayne, J. T., Mortimer, P., Worsnop, D. R., Kolb, C. E., Johnson, K. S., Zuberi, B., Marr, L. C., Volkamer, R., Molina, L. T., Molina, M. J., Cardenas, B., Bernabé, R. M., Márquez, C., Gaffney, J. S., Marley, N. A., Laskin, A., Shutthanandan, V., Xie, Y., Brune, W., Lesher, R., Shirley, T., and Jimenez, J. L.: Characterization of ambient aerosols in Mexico City during the MCMA-2003 campaign with Aerosol Mass Spectrometry: results from the CENICA Supersite, Atmos. Chem. Phys., 6, 925-946, doi:10.5194/acp-6-925-2006, 2006.

Schmid, H. P., Grimmond, C. S. B., Cropley, F., Offerle, B., and $\mathrm{Su}, \mathrm{H}$. B.: Measurements of $\mathrm{CO} 2$ and energy fluxes over a mixed hardwood forest in the mid-western United States, Agr. Forest Meteorol., 103, 357-3774, 2000.

SMA-GDF: (Secretaría del Medio Ambiente, Gobierno del Distrito Federal). Programa de Acción Climática de la Ciudad de México 2008-2012, 2008.

Stewart, I. D. and Oke, T. R.: Thermal differentiation of local climate zones using temperature observations from urban and rural field sites, Symposium on Urban Environment, Keystone, CO, USA, 2010,

Thomas, R. M.: Measurement of speciated aerosol fluxes, Ph.D. thesis, Ph.D., University of Manchester, Manchester, UK, 2007.

Ulbrich, I. M., Canagaratna, M. R., Cubison, M. J., Zhang, Q., Ng, N. L., Aiken, A. C., and Jimenez, J. L.: Three-dimensional factorization of size-resolved organic aerosol mass spectra from Mexico City, Atmos. Meas. Tech., 5, 195-224, doi:10.5194/amt-5195-2012, 2012.

Ulbrich, I. M., Canagaratna, M. R., Zhang, Q., Worsnop, D. R., and Jimenez, J. L.: Interpretation of organic components from Positive Matrix Factorization of aerosol mass spectrometric data, At- mos. Chem. Phys., 9, 2891-2918, doi:10.5194/acp-9-2891-2009, 2009.

United Nations, Department of Economic and Social Affairs, Population Division: World Urbanization Prospects, the 2009 Revision: Press Release, New York, USA, 2010.

Velasco, E., Lamb, B., Pressley, S., Allwine, E., Westberg, H., Jobson, B. T., Alexander, M., Prazeller, P., Molina, L. T., and Molina, M.: Flux measurements of volatile organic compounds from an urban landscape, Geophys. Res. Lett., 32, L20802,, doi:10.1029/2005GL023356, 2005a.

Velasco, E., Pressley, S., Allwine, E., Westberg, H., and Lamb, B.: Measurements of $\mathrm{CO}_{2}$ fluxes from the Mexico City urban landscape, Atmos. Environ., 39, 7433-7446, 2005 b.

Velasco, E., Pressley, S., Grivicke, R., Allwine, E., Coons, T., Foster, W., Jobson, B. T., Westberg, H., Ramos, R., Hernández, F., Molina, L. T., and Lamb, B.: Eddy covariance flux measurements of pollutant gases in urban Mexico City, Atmos. Chem. Phys., 9, 7325-7342, doi:10.5194/acp-9-7325-2009, 2009.

Velasco, E., Pressley, S., Allwine, E., Grivicke, R., Molina, L. T., and Lamb, B.: Energy balance in urban Mexico City: observation and parameterization during the MILAGRO/MCMA2006 field campaign, Theor. Appl. Climatol., 103, 501-517, doi:10.1007/s00704-010-0314-7, 2011.

Vickers, D., and Mahrt, L.: Quality control and flux sampling problems for tower and aircraft data., J. Atmos. Ocean. Technol., 14, 512-526, 1997.

Vogt, M., Nilsson, E. D., Ahlm, L., Mårtensson, E. M., and Johansson, C.: The relationship between $0.25-2.5 \mu \mathrm{m}$ aerosol and $\mathrm{CO}_{2}$ emissions over a city, Atmos. Chem. Phys., 11, 4851-4859, doi:10.5194/acp-11-4851-2011, 2011.

Volkamer, R., Jimenez, J. L., San Martini, F., Dzepina, K., Zhang, Q., Salcedo, D., Molina, L. T., Worsnop, D. R., and Molina, M. J.: Secondary Organic Aerosol Formation from Anthropogenic Air Pollution: Rapid and Higher than Expected, Geophys. Res. Lett., 33, L17811, doi:10.1029/2006GL026899, 2006.

Webb, E. K., Pearman, G. I., and Leuning, R.: Correction of the Flux Measurements for Density Effects Due to Heat and Water Vapour Transfer, Q. J. Roy. Meteorol. Soc., 106, 85-100, 1980.

Yokelson, R. J., Urbanski, S. P., Atlas, E. L., Toohey, D. W., A1varado, E. C., Crounse, J. D., Wennberg, P. O., Fisher, M. E., Wold, C. E., Campos, T. L., Adachi, K., Buseck, P. R., and Hao, W. M.: Emissions from forest fires near Mexico City, Atmos. Chem. Phys., 7, 5569-5584, doi:10.5194/acp-7-5569-2007, 2007.

Zhang, Q., Alfarra, M. R., Worsnop, D. R., Allan, J. D., Coe, H., Canagaratna, M. R., and Jimenez, J. L.: Deconvolution and quantification of hydrocarbon-like and oxygenated organic aerosols based on aerosol mass spectrometry, Environ. Sci. Technol., 39, 4938-4952, 2005.

Zheng, J., Zhang, R., Fortner, E. C., Volkamer, R. M., Molina, L., Aiken, A. C., Jimenez, J. L., Gaeggeler, K., Dommen, J., Dusanter, S., Stevens, P. S., and Tie, X.: Measurements of $\mathrm{HNO}_{3}$ and $\mathrm{N}_{2} \mathrm{O}_{5}$ using ion drift-chemical ionization mass spectrometry during the MILAGRO/MCMA-2006 campaign, Atmos. Chem. Phys., 8, 6823-6838, doi:10.5194/acp-8-6823-2008, 2008. 